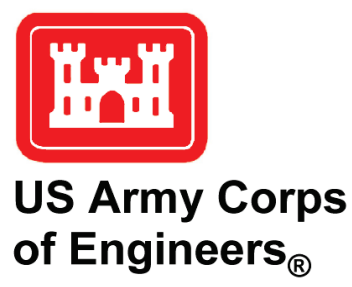

\title{
The Coastal Model Test Bed Initialization and Setup: CMS-Wave
}

by Spicer Bak, Zeki Demirbilek, and Lihwa Lin

PURPOSE: The purpose of this Coastal and Hydraulics Engineering Technical Note (CHETN) is to describe the implementation of the CMS-Wave model into the Coastal Model Test Bed (CMTB). The CMTB has been initiated to evaluate and understand the strengths and weaknesses of numerical wave, hydrodynamic, and morphologic models using high-resolution temporal and spatial field measurements available at the Coastal and Hydraulics Laboratory (CHL), Field Research Facility (FRF), in Duck, NC. This field evaluation will promote rapid enhancement of model capability and focus research efforts in the coastal environment. Detailed information about the CMTB, initial setup methodology, and the first group of tested models can be found in Bak et al. (2017). Only a summary of the methodology is described in this document.

BACKGROUND: Numerical models are used by engineers, scientists, and coastal planners in U.S. Army Corps of Engineers (USACE) Districts, U.S. Army Engineer Research and Development Center (ERDC), and academia as well as in industry to simulate complex, coastal dynamics at a reasonable cost. One of the challenges for coastal studies is the reliability of predicting the nearshore waves. Two-dimensional (2D) non-linear phase-resolving wave models are computationally demanding. Therefore, a commonly used alternative is a simpler and more computationally efficient phase-averaged wave model for wind-wave generation. Nearshore numerical wave models have been in use by coastal engineers for decades. As the state of the science progresses, new physics packages are added or new models are developed (Battjes and Janssen 1978; Demirbilek and Panchang 1998; Booij et al. 1999; Smith et al. 1999). With each of these new packages, model results are validated using laboratory or field measurements. Oftentimes model validation studies are limited by data, specifically data that are available in only a few conditions or locations. There have been previous efforts to evaluate models more thoroughly through a test bed idea (e.g., Ris et al. 2002), though with limited longevity.

The FRF has collected a variety of field data over the past 40 years. Historically, these data have been used in a limited way to verify new model physics (e.g., specific experiments). With the implementation of the CMTB at the FRF, numerical models are now run concurrently with a data collection program (Bak et al. 2017), allowing for testing and validation of numerical models in near real-time under a broad range of conditions against observation data. Consequently, with the extensive field data at the FRF, the CMTB provides a unique opportunity to thoroughly evaluate numerical wave models for a wide range of conditions.

Validation with a data set of time-varying field observations helps to assess model error and uncertainty associated with predictions. Testing with a wide range of field conditions helps to identify model deficiencies for naturally variable, open-coast conditions. Once deficiencies are 
identified, research directives can be targeted to develop improvements, and the process can easily be cycled through evaluation again. This process can lead to efficient model improvements.

The CMTB is built in a modular way such that the test bed framework can be applied to other computing platforms or modeled locations with minimal additional effort. The near-live environment that the test bed operates in helps keep up with the computational load required to compute the high number of simulations required for the various different models. The first implementation of the CMTB incorporated the STWAVE model (Bak et al. 2017) with a followon addition of the one-dimensional profile evolution model CSHORE (Young et al. 2018). The stand-alone wave model version of the Coastal Modeling System (CMS) (Lin, Demirbilek, and Mase 2011) is the third model implemented. Concurrently, development of the internally coupled "in line" code to improve efficiency of coupling between wave, circulation, and sediment transport models is ongoing by the CMS development team. In future testing, both this version of the code as well as the traditional stand-alone (wave only) code will be evaluated to ensure similitude. For this CHETN, the model is set up using the stand-alone version of CMS-Wave compiled for a Linux Centos 7 operating system.

DATA: The FRF is located on the Atlantic Ocean coast in the northern Outer Banks of North Carolina and has a very mild planar beach that extends miles into the Outer Continental Shelf of the United States. In situ instruments at the FRF continuously measure waves, winds, water levels, and currents. Waves are measured at the FRF in depths of 26 meters (m) and $17 \mathrm{~m}$ with Waverider buoys (Coastal Data Information Program 403 and 433, respectively); in $11 \mathrm{~m}, 8 \mathrm{~m}, 6 \mathrm{~m}$, and 4.5 $\mathrm{m}$ with bottom-mounted Acoustic Wave and Current profilers (AWAC); in $3.5 \mathrm{~m}$ with an Acoustic Doppler Profiler; and with three buried Paroscientific pressure gauges at nominal depths ranging from 0 to $3 \mathrm{~m}$ mean sea level. Table 1 provides a summary of the array of gauges used in this study, and Bak et al. (2017) provide a spatial reference to location. The collection of gauges is referred to herein as the cross-shore array.

\begin{tabular}{|c|c|c|c|c|c|}
\hline Gauge Type & $\begin{array}{l}\text { Nominal } \\
\text { Depth, } \\
\text { [m] }\end{array}$ & Measurement Type & $\begin{array}{l}\text { FRF Cross- } \\
\text { Shore } \\
\text { coordinate [m] }\end{array}$ & $\begin{array}{l}\text { FRF Alongshore } \\
\text { Coordinate }[\mathrm{m}]\end{array}$ & $\begin{array}{c}\text { Sample } \\
\text { Frequency, } \\
\mathrm{Hz}\end{array}$ \\
\hline Waverider & 26 & Directional wave & 16,266 & 4,136 & 1.28 \\
\hline Waverider & 17 & Directional wave & 3,716 & 1,417 & 1.28 \\
\hline AWAC & 11 & $\begin{array}{c}\text { Directional wave and } \\
\text { current }\end{array}$ & 1,272 & 910 & 2 \\
\hline $8 \mathrm{~m}$ array & 8 & $\begin{array}{l}\text { Directional wave (Long and } \\
\text { Oltman-Shay 1991) }\end{array}$ & 917 & 935 & 2 \\
\hline AWAC & 6 & $\begin{array}{c}\text { Directional wave and } \\
\text { current }\end{array}$ & 605 & 938 & 2 \\
\hline AWAC & 4.5 & $\begin{array}{c}\text { Directional wave and } \\
\text { current }\end{array}$ & 400 & 940 & 2 \\
\hline Aquadopp & 3.5 & $\begin{array}{l}\text { Directional wave, current, } \\
\text { and bottom elevation }\end{array}$ & 300 & 940 & 2 \\
\hline $\begin{array}{l}\text { Pressure - } \\
\text { xp200 }\end{array}$ & 2.8 & $\begin{array}{c}\text { Point wave and bottom } \\
\text { elevation }\end{array}$ & 200 & 940 & 2 \\
\hline $\begin{array}{l}\text { Pressure - } \\
\text { xp150 }\end{array}$ & 2.1 & $\begin{array}{c}\text { Point wave and bottom } \\
\text { elevation }\end{array}$ & 150 & 940 & 2 \\
\hline $\begin{array}{l}\text { Pressure - } \\
\quad \text { xp125 }\end{array}$ & 1.9 & Point wave & 125 & 940 & 2 \\
\hline
\end{tabular}


BATHYMETRY METHODOLOGY AND DOMAIN: The computational grid for the CMSWave model extends offshore to just beyond the $26 \mathrm{~m}$ Waverider, covers 15.5 kilometers $(\mathrm{km})$ alongshore, centrally located around the FRF pier, and extends a few hundred meters west of the shoreline. The cross-shore orientation of the grid paralleled the FRF pier with an angle of 71.8 degrees to true north. The model is set up with a variable grid resolution ranging from $15 \mathrm{~m}$ nearshore to $280 \mathrm{~m}$ in the alongshore and $10 \mathrm{~m}$ to $230 \mathrm{~m}$ in the cross-shore, with the smallest grid spacing located closest to the nearshore array (Figure 1).

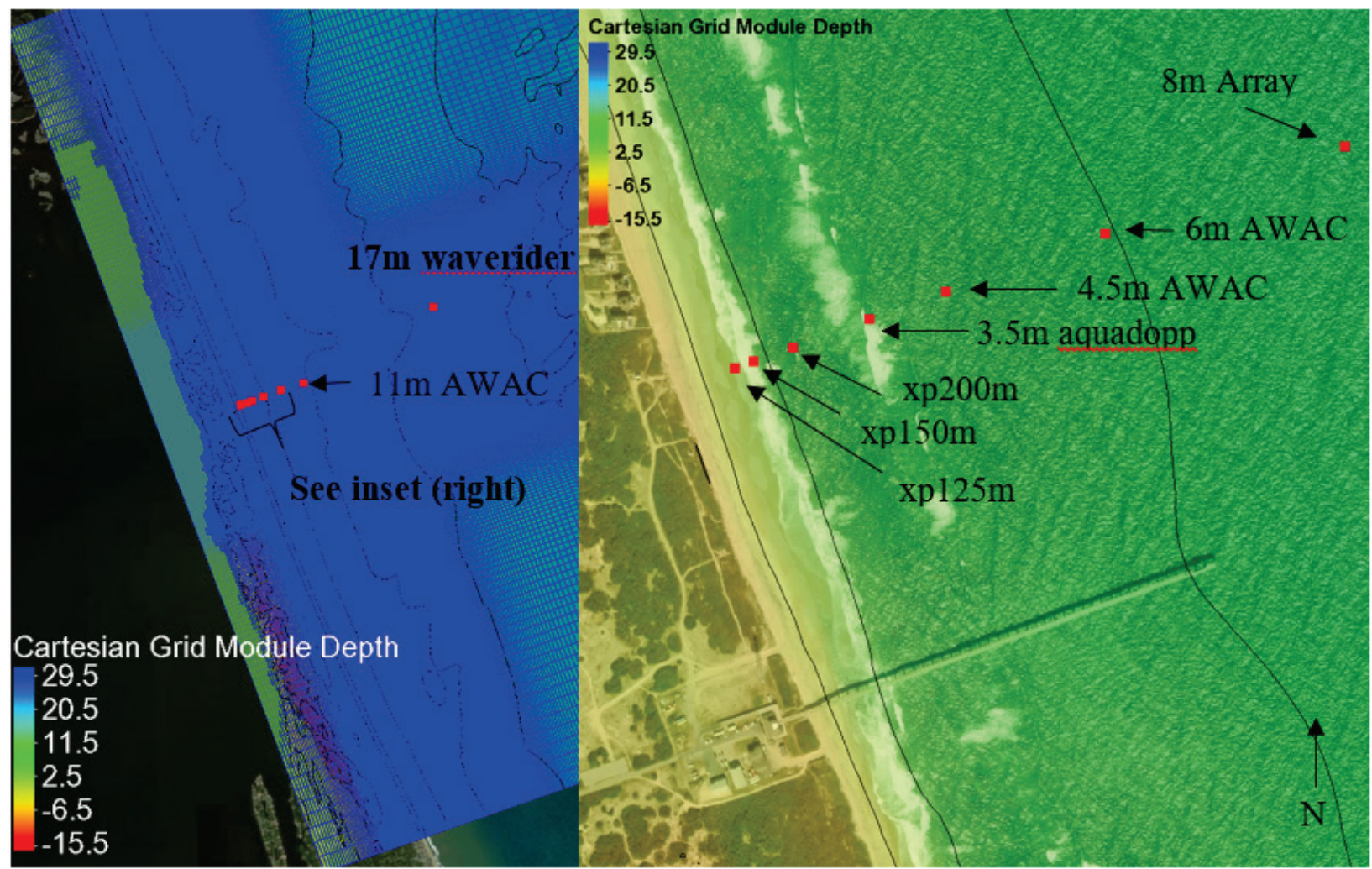

Figure 1. CMS-Wave regional bathymetry and grid cells (left) and zoomed in view of FRF property and position of the cross-shore array of wave gauges - red squares - in the nearshore (right).

The bathymetric boundary condition used in this model is updated with every new survey measurement. The latest bathymetry is splined into a larger domain, outlined in Young et al. (2018), which is produced for all models in the CMTB; then, to accommodate the CMS-Wave grid, the bathymetry is linearly interpolated to the needed resolution in the model grid. The portion of bathymetry that is updated depends on the most recent measurements, but data generally extend the distance of the FRF property in the alongshore $(1.4 \mathrm{~km})$ and to depths of $12 \mathrm{~m}$, where no significant bathymetric change is expected. The model pre- and post-processing workflow is performed in Python.

MODEL SETUP: The model is forced using the 2D energy spectra measured from a Waverider buoy in $26 \mathrm{~m}$ water depth. Redundant wind measurements are made at the end of the FRF pier to ensure highest quality data at all times. Based on quality assurance/quality control, factors, the best 10-minute wind data are selected in real-time then vector averaged, elevation corrected to $10 \mathrm{~m}$ to produce a wind that is applied as spatially constant across the domain. The water level is measured 
at the end of the pier at a 6-minute interval, which is then scalar averaged and applied as spatially constant across the domain to account for tides and storm surge National Oceanic and Atmospheric Administration station ID 8651370). The initial setup of the model using the default switches is shown in Table 2.

\section{Table 2. Model settings utilized in the current setups.}

\begin{tabular}{|l|c|l|l||}
\hline Setting & Value & Switch Description & Notes \\
\hline iprp & -1 & Propagation and wave generation & $\begin{array}{l}\text { Run with both wind/wave generation and } \\
\text { in fast mode }\end{array}$ \\
\hline icur & 0 & Wave/current interaction & Off \\
\hline ibrk & 0 & Wave breaker file & Currently off, plans to implement \\
\hline irs & 0 & Radiation stress output & Currently off, plans to implement \\
\hline kout & 10 & Number of spectral output locations & $\begin{array}{l}\text { One at each of the cross-shore array of } \\
\text { wave gauges }\end{array}$ \\
\hline ibnd & 0 & Nesting boundary input & Off \\
\hline iwet & 0 & Wetting/drying & Controlled with water level \\
\hline ibf & 1 & Bottom friction & Darcy-Weisbach type (Cf) \\
\hline iark & 1 & Forward reflection & On \\
\hline iarkr & 0 & Backward reflection & Off \\
\hline akap & 4 & Diffraction intensity & 4 is maximum diffraction \\
\hline bf & 0.005 & Friction factor & Spatially constant \\
\hline ark & 0.3 & Constant forward reflection factor & 1 is maximum \\
\hline arkr & 0.3 & Constant backward reflection factor & $\begin{array}{l}\text { 1 is maximum, (turned off, see iarkr } \\
\text { above) }\end{array}$ \\
\hline iwvbk & 0 & Wave breaker selection criteria & Extended Goda selected (Goda 1975) \\
\hline nonln & 0 & Non-linear wave interaction & Off \\
\hline igrav & 0 & Infragravity wave & Off \\
\hline irunup & 0 & Wave runup & Off \\
\hline imud & 1 & Mud effect & Off \\
\hline iwind & 1 & Wind input & Spatially constant \\
\hline isolv & 0 & Solver selection & Gauss-Seidel solver \\
\hline ixmdf & 0 & Input/output selection & ASCll format \\
\hline iproc & 1 & Number of processors & Run in half-plane mode \\
\hline iview & 0 & Half/full plane mode & Optional \\
\hline iroll & 0 & $\begin{array}{l}\text { Wave roller intensity factor (0 for no } \\
\text { effect, 4 for strong effect) }\end{array}$ & \\
\hline
\end{tabular}

PERFORMANCE EVALUATION EXAMPLE FOR CMS-WAVE: To ensure the CMS-Wave model is compiled and running properly on a Linux OS, a test run was performed to check model performance for the time period of October through November 2015 at the $3.5 \mathrm{~m}$ Aquadopp. This gauge is nearest to shore, providing directional wave data (Table 1). From 21 October through 30 November 2015, the offshore wave climate was a mix of smaller waves (wave height $-\mathrm{H}_{\mathrm{m} 0}<1 \mathrm{~m}$ ) with occasional periods of moderately sized waves $\left(\mathrm{H}_{\mathrm{m} 0}>2 \mathrm{~m}\right)$. The wave period ranged from shorter waves $\left(6\right.$ seconds $[\mathrm{s}]<$ wave peak period $\left.-\mathrm{T}_{\mathrm{p}}<10 \mathrm{~s}\right)$ times and longer waves $(10 \mathrm{~s}<$ wave 
peak period $<15 \mathrm{~s}$ ). There were five events with wave heights over $2 \mathrm{~m}$ ranging in durations from as short as a few hours to over 5 days (Figure 2).

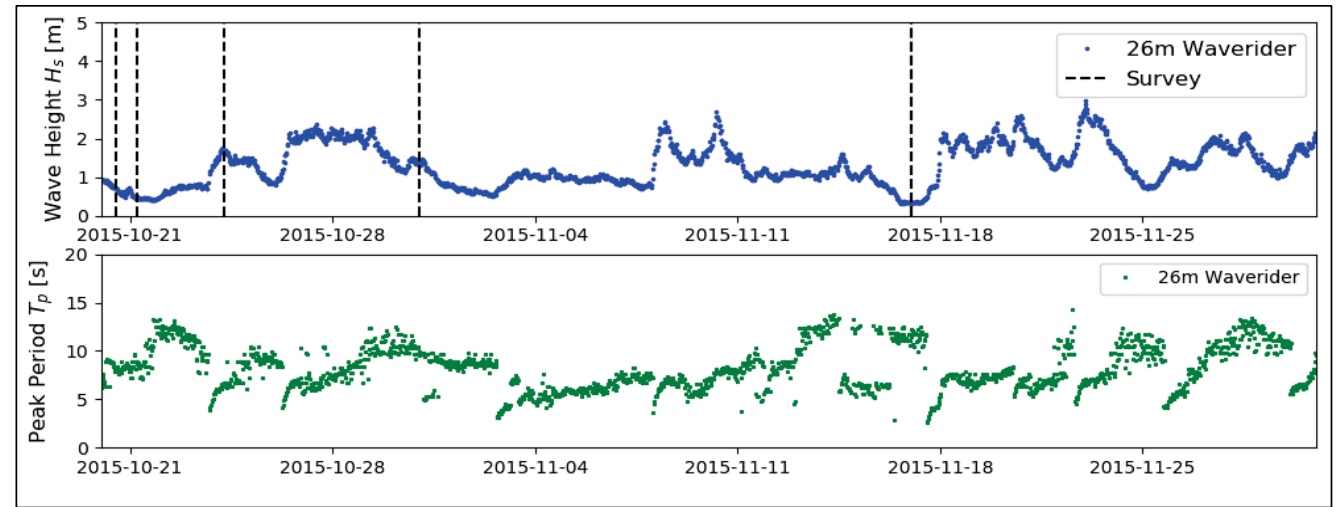

Figure 2. Offshore wave conditions measured at the $26 \mathrm{~m}$ Waverider buoy, wave height (top) wave period (bottom). The vertical black lines are when bathymetric surveys were conducted.

For comparisons between model and observations, the 2D (frequency-direction) energy spectrum was extracted at grid cells co-located with the gauge, and bulk statistics were calculated for model and observation data. These first-order statistics of bulk spectral parameters, listed below, were used to check model performance. These included the significant wave height $\left(H_{m o}\right.$ or $\left.H_{s}\right)$ :

$$
H_{m o}=4 * \sqrt{\iint E(f, \theta) d f d \theta}
$$

where $\mathrm{E}(\mathrm{f}, \theta)$ is the $2 \mathrm{D}$ frequency-direction energy spectrum. The mean period, $T_{m}$, was calculated as

$$
T_{m}=\frac{\int E(f) d f}{\int f^{-1} * E(f) d f}
$$

where $\mathrm{E}(\mathrm{f})$ is the frequency-energy spectrum. The mean direction, $\theta_{M E A N}$, was calculated as

$$
\begin{gathered}
\theta_{\text {MEAN }}=\arctan \left(X_{\text {comp }}, Y_{\text {comp }}\right) \\
X_{\text {comp }}=\frac{\iint \sin (\theta) \cdot E(f, \theta) d f d \theta}{\iint E(f, \theta) d f d \theta} ; \quad Y_{\text {comp }}=\frac{\iint \cos (\theta) \cdot E(f, \theta) d f d \theta}{\iint E(f, \theta) d f d \theta}
\end{gathered}
$$

Figure 3 shows time-series comparison plots at the $3.5 \mathrm{~m}$ Aquadopp between observation and simulation data for October and November of 2015 as well as comparison plots for significant wave height $-H_{m o}$ (Figure $3 \mathrm{a}$ and $\mathrm{d}$ ), mean period $-T_{m}$ (Figure $3 \mathrm{~b}$ and e), and mean Direction $\theta_{M E A N}($ Figure $3 \mathrm{c}$ and $\mathrm{f}$ ). The significant wave height and mean period predicted by the model 
compared well to measured data over the duration, with a greater discrepancy in the mean wave direction (Figure 3 and Table 3).
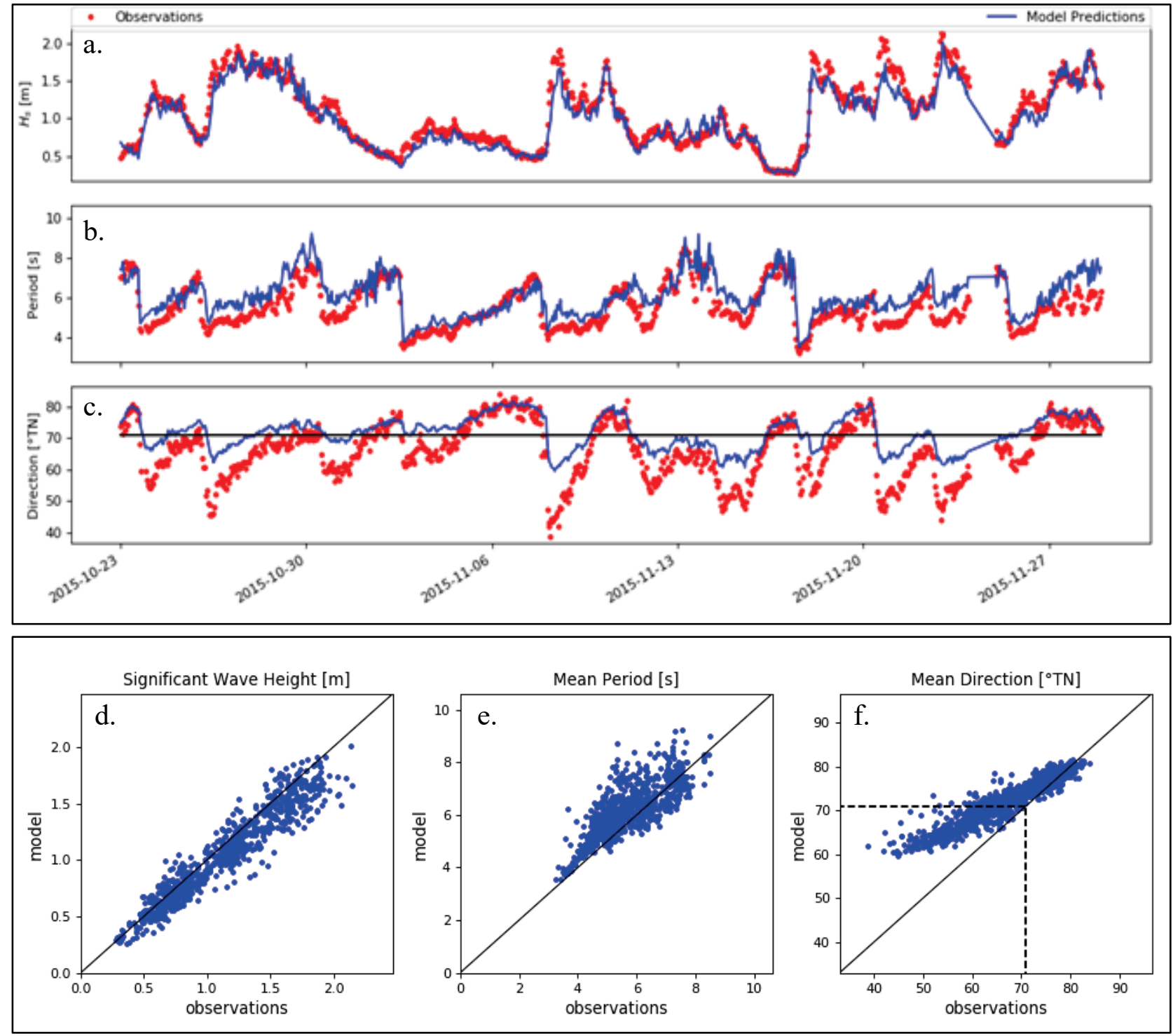

Figure 3. Time-series comparison between model predictions and measured values of (a) $\mathrm{H}_{\mathrm{mo}}$, (b) $\mathrm{T}_{\mathrm{m}}$, and (c) $D_{m}$ for the $3.5 \mathrm{~m}$ Aquadopp between October and November of 2015. Comparison plots are shown for (d) $\mathrm{H}_{\mathrm{m} 0}$, (e) $\mathrm{T}_{\mathrm{m}}$, and (f) $\mathrm{D}_{\mathrm{m}}$ (the dashed line shows shore normal) for the same time period.

Listed in Table 3 is the cumulative bulk spectral statistic comparison of the calculated model data to measured data for this time period, as outlined by Bryant et al (2016). At the $3.5 \mathrm{~m}$ Aquadopp station, the significant wave height has a bias and root mean square error (RMSE) of $-0.08 \mathrm{~m}$ and $0.15 \mathrm{~m}$, respectively. The mean direction at the $3.5 \mathrm{~m}$ aquadop has bias and RMSE of $5.74^{\circ}$ and $7.36^{\circ}$, respectively. 


\begin{tabular}{|c|c|c|c|}
\hline & $\mathrm{H}_{\mathrm{mo}}$ & $T_{m}$ & $\theta_{\text {MEAN }}$ \\
\hline Bias & $-0.08 \mathrm{~m}$ & $0.52 \mathrm{~s}$ & $5.74^{\circ}$ \\
\hline RMSE & $0.15 \mathrm{~m}$ & $0.84 \mathrm{~s}$ & $7.36^{\circ}$ \\
\hline RMSE - Demeaned & $0.13 \mathrm{~m}$ & $0.65 \mathrm{~s}$ & $4.61^{\circ}$ \\
\hline RMSE - Normalized & $13 \%$ & $15 \%$ & $11 \%$ \\
\hline Scatter Index & 0.14 & 0.15 & 0.11 \\
\hline $\mathrm{R}^{2}$ & 0.92 & 0.63 & 0.87 \\
\hline Symmetrical Slope & 0.93 & 1.09 & 1.08 \\
\hline Performance Score (Willmott et al. 1985) & 0.85 & 0.61 & 0.57 \\
\hline Performance Score (Hanson, Friebel, and Hathaway 2009) & 0.90 & 0.88 & 0.90 \\
\hline
\end{tabular}

The model-data comprison shows that the significant wave height $\left(H_{m 0}\right)$, was adequtately resolved for smaller wave heights while underpredicting during larger events, as evidendced by a symetric slope below unity (0.93) (see Table 3 and Figure $3 \mathrm{a}$ and d). The mean period, $T_{m}$, was generally overpredicted by the model (see Figure $3 \mathrm{~b}$ and $\mathrm{d}$ ) and has a low correlation to observations $\left(\mathrm{R}^{2}=\right.$ 0.63 in Table 3 ). The mean wave direction, $\theta_{M E A N}$, was well resolved with wave events approaching from the south $\left(\theta_{M E A N}>72\right.$ in Figure $3 \mathrm{c}$ and $\left.\mathrm{f}\right)$ but was less resolved $(\theta<72$ in Figure $3 \mathrm{c}$ and $\mathrm{f})$ for waves from the north. This may be related to the elongated, low-sloping continental shelf to the north of the FRF. Additional work is recommended to further investigate these findings. Model setups will inevitably change (for the most recent setup, please refer to $w w w$.frf.usace.army.mil/CMTB). Note that these results are preliminary and should not be used to draw conclusions on the overall performance of the model. The objective of this study was to set up the CMS-Wave model for the CMTB to demonstrate some of the capability of the test bed framework.

CONCLUSION AND FUTURE WORK: The phase-averaged CMS-Wave model was set up in the CMTB to compile, run, and evaluate model performance and archive simulation results. A short model-observation comparison for a little over a month period at the end of 2015 demonstrated comparison methods and statistical performance output within the CMTB. This effort is built upon previous CMTB development efforts to facilitate inclusion of new wave models in the test bed. As the project evolves, new metrics for model validation and performance will incorporate evaluated wave runup and breaking using optical imagery and lidar data. CMS-Wave and other numerical models will be evaluated in greater detail, identifying areas for improvement after extensive testing using a broad range of natural conditions observed at the FRF.

ADDITIONAL INFORMATION: This CHETN was prepared as part of the USACE, Coastal Inlets Research Program (CIRP), U.S. Army Engineer Research and Development Center, CHL, Vicksburg, MS. Questions pertaining to this CHETN may be directed to Spicer Bak (spicer.bak@usace.army.mil); the USACE CIRP Program Manager is Tanya M. Beck (Tanya.M.Beck@usace.army.mil). Additional information regarding CIRP may be obtained from the CIRP website http://cirp.usace.army.mil/. 
This CHETN should be cited as follows:

Bak, S., Z. Demirbilek, and L. Lin. 2019. The Coastal Model Test Bed Initialization and Setup: CMS-Wave. ERDC/CHL CHETN-I-97. Vicksburg, MS: U.S. Army Engineer Research and Development Center. $\underline{\text { http: } / / d x \text {.doi.org/10.21079/11681/33643 }}$

\section{REFERENCES}

Bak, S., T. Hesser, J. Smith, and M. Bryant. 2017. Initialization and Setup of the Costal Model Test Bed: STWAVE. ERDC/CHL CHETN-I-93. Vicksburg, MS: U.S. Army Engineer Research and Development Center.

Battjes, J. A., and J. P. F. M. Janssen. 1978. "Energy Loss and Set-Up Due to Breaking of Random Waves.” Coastal Engineering Proceedings. doi: 10.9753/icce.v16.\%p

Booij, N. R. R. C., R. C. Ris, and L. H. Holthuijsen. 1999. "A Third-Generation Wave Model for Coastal Regions: 1. Model Description and Validation." Journal of Geophysical Research: Oceans 104(C4): 7649-7666.

Bryant, M. A., T. J. Hesser, and R. E. Jensen. 2016. Evaluation Statistics Computed for the Wave Information Studies (WIS). ERDC/CHL CHETN-I-91. U.S. Army Engineer Research and Development Center. http://www.dtic.mil/get-tr-doc/pdf? AD=AD1013235

Demirbilek, Z., and V. Panchang. 1998. CGWAVE: A Coastal Surface Water Wave Model of the Mild Slope Equation. Technical Report CHL-98-26. Vicksburg, MS: U.S. Army Engineer Waterways Experiment Station.

Goda, Y. 1975. "Irregular Wave Deformation in the Surf Zone.” Coastal Engineering in Japan 18(1): 13-26. doi: $10.1080 / 05785634.1975 .11924196$

Hanson, J., H. Friebel, and K. Hathaway. 2009. “Coastal Wave Energy Dissipation: Observations and STWAVE-FP performance." 11TH International Workshop on Wave Hindcasting and Forecasting and 2nd Coastal Hazards Symposium, 18-23.

Lin, L., Z. Demirbilek, and H. Mase. 2011. "Recent Capabilities of CMS-Wave: A Coastal Wave Model for Inlets and Navigation Projects." Journal of Coastal Research 59(Special Issue 59): 7-14. http://www.jcronline.org/doi/abs/10.2112/SI59-002.1

Long, C., and J. Oltman-Shay. 1991. Directional Characteristics of Waves in Shallow Water. CERC-91-1. Vicksburg, MS: U.S. Army Engineer Waterways Experiment Station.

Ris, R. C., J. M. Smith, L. Holthuijsen, and N. Booij. 2002. "The ONR Virtual Testbed for Coastal and Oceanic Wave Models.” In Proc. 28th Int. Conf. Coastal Eng., 380-391.

Smith, J. M., D. T. Resio, and A. K. Zundel. 1999. STWAVE: Steady-State Spectral Wave Model. Report 1: User's Manual for STWAVE Version 2.0. Instruction Report CHL-99-1. Vicksburg, MS: U.S. Army Engineer Waterways Experiment Station.

Willmott, C. J., S. G. Ackleson, R. E. Davis, J. J. Feddema, K. M. Klink, D. R. Legares, J. O’Donnell, and C. M. Rowe. 1985. "Statistics for the Evaluation and Comparison of Models." Journal of Geophysical Research 90(C5): 8995-9005. doi: 10.1029/JC090iC05p08995

Young, D., S. Bak, and B. D. Johnson. 2018. Initialization and Setup of the Coastal Model Test Bed: CSHORE. ERDC/CHL CHETN-IV-115. Vicksburg, MS: U.S. Army Engineer Research and Development Center.

Young, D. L., A. S. Bak, and M. F. Forte. 2018. Initialization and Setup of the Coastal Model Test Bed: Integrated Bathymetry. ERDC/CHL CHETN-IV-113. Vicksburg, MS: U.S. Army Engineer Research and Development Center.

NOTE: The contents of this technical note are not to be used for advertising, publication, or promotional purposes. Citation of trade names does not constitute an official endorsement or approval of the use of such products. 